\title{
SPATIAL AND TEMPORAL DYNAMIC OF RURAL AND URBAN LANDSCAPES IDENTIFIED IN THE “IRON GATES” NATURAL PARK
}

\author{
Mihăiţă-Iulian NICULAE *, Mihai Răzvan NIŢÄ*, \\ Gabriel VAN $\breve{U}$ *, Cristiana CIOCANEA * and Athanasios GAVRILIDIS *
}

* University of Bucharest, Centre for Environmental Research and Impact Studies, Nicolae Bălcescu Boulevard 1, Sector 1, CP 010041, Bucharest, Romania, mihaitaiulian.niculae@g.unibuc.ro, mihairazvan.nita@g.unibuc.ro, gabriel.vanau@geo.unibuc.ro, cristianamaria.ciocanea@g.unibuc.ro, athanasiosalexandru.gavrilidis@g.unibuc.ro

DOI: 10.1515/trser-2015-0043

KEYWORDS: Rural and urban landscape, land use, land cover, landscape change, "Iron Gates” Natural Park, Romania.

\section{ABSTRACT}

In the present paper, we identified landscape typologies in the "Iron Gates" Natural Park from Romania and assessed their dynamic starting with 1990 to 2006. We evaluated the dynamic of landscapes based on land use and land covers changes as extracted from the Corine Land Cover databases. We found no major modifications in the distribution of landscapes, only $4.4 \%$ of the study area recording changes. Forestry landscapes have the highest ratio of change (on $1.5 \%$ from the total surface of the park), with significant decreases also recorded in landscapes of shrub and rare vegetation, as well as mixed agricultural landscapes. Among the active transformation processes, forestation (on $45 \%$ of the modified surface) and agricultural activities (20\%) recorded the highest distribution.

RÉSUMÉ: La dynamique spatiale et temporelle des paysages ruraux et urbains dans le Parc Naturel des "Portes de Fer".

L'article fait un inventaire des catégories de paysages qui se trouvent dans le Parc Naturel des "Portes de Fer" des Roumanie et analyse la dynamique de ces paysages de 1990 à 2006. L’analyse de la dymamique a été réalisée en prenant en considération les changements des modes d'utilisation des terrains quantifiés avec les données de CORINE Land Cover. Les changements n'ont pas été majeurs, la surface modifiée étant de $4.4 \%$ du total du territoire. La croissance la plus importante de la superficie a été enregistrée pour les paysages forestiers (1.5\% du total du parc). Des réductions plus importantes ont été enregistrées pour les broussailles et les paysages avec moins de végétation naturelle, en incluant ici les terrains agricoles mixtes. Comme processus de transformation, la régénération des forêts a représenté (45\% du total de la superficie modifiée) et l'agriculture de type intensive (a représenté 20\%).

REZUMAT: Dinamica spațială și temporală a peisajelor rurale și urbane identificate în arealul Parcului Natural Porţile de Fier.

Lucrarea își propune să identifice categoriile de peisaje din cadrul Parcului Natural „Porțile de Fier” din România, și să evalueze dinamica acestora în intervalul 1990 la 2006. Evaluarea dinamicii s-a realizat pe baza analizei schimbării modului de utilizare al terenurilor, utilizând datele CORINE LandCover. În intervalul analizat nu s-au înregistrat schimbări majore, suprafața modificată fiind de $4.4 \%$ din totalul arealului. Cele mai mari creșteri ale suprafețelor s-au înregistrat în cazul peisajelor forestiere $(1.5 \%$ din suprafața parcului). Diminuări însemnate s-au înregistrat în cazul suprafețelor cu tufărișuri și cele cu vegetație rară, coroborate cu cele agricole mixte. În ceea ce privește procesele de transformare identificate, împăduririle au ocupat cea mai mare suprafață ( $45 \%$ din suprafața modificată), completate de intensificarea agriculturii (20\% din suprafața modificată). 


\section{INTRODUCTION}

According to the European Landscape Convention (Council of Europe, 2000), the landscape designates parts of a territory perceived by the population; its characteristics being a result of actions and interactions between natural and human factors. Landscapes contribute to sustainable development and human well-being, with its recognized functions as the social, cultural, economic or ecological ones (Prieur, 2006). Landscapes spatial and temporal dynamic represents subjects of interest for researchers at different spatial scales (Niculae, 2012).

In protected areas, landscapes are considered a component of the natural material heritage (Grigorovschi et al., 2007), with its complexity and characteristics determined by the interaction of three main components: abiotic potential (as a support for the other two), biodiversity and cultural diversity (Pătroescu et al., 2000; Pătru-Stupariu, 2011; Toma, 2008). The landscape is seen as a materialization of the natural capital and present land use (Feranec et al., 2002), representing a symbolic element of social dialogue between communities through its connections at diverse spatial and temporal scales (Faburel et al., 2012).

In analysing landscape dynamic the CLC database, aerial images and existing maps represent important data sources as the land use is one of the most used indicators (Feranec et al., 2002). Monitoring the changes in land uses and land covers of a certain territory represents an important instrument in assessing the manner to which policies and public measures influence the use of natural resources by the population (Thiha and Honda, 2007). Changes in land uses are determined by the intensification of certain land-use forms, whilst changes in land cover relate both to their conversion (changing into another class) and modification of the characteristic conditions (Coppin et al., 2004).

In Romanian protected areas with large surfaces (national and natural parks, Natura 2000 sites), landscapes represent an important component as they integrate patrimonial values of natural or cultural elements. Landscapes represent elements conferring identity, individuality, and often uniqueness to protected areas of national interest which contribute to the protection and conservation of landscape structures and functionality. The identification of defining elements of landscapes and their typologies represents an essential instrument in analysing their spatial and temporal dynamic. In addition - in the case of protected areas - it represents a tool for developing an adequate landscape management, useful both to protected areas managers and spatial planners at local or regional scales.

The aim of our study is to analyze, landscape dynamic in the "Iron Gates" Natural Park from 1990 onwards. The objectives of our paper are: a) identifying landscape typologies in the "Iron Gates" Natural Park, and b) evaluating the spatial and temporal dynamic of landscape typologies in the study area in the period of significant social and economic changes, and to return to a private properties regime and establishment of the protected area.

\section{MATERIAL AND METHODS}

The "Iron Gates" Natural Park was established through Law 5/2000 regarding the National Planning Framework, Section III - protected areas (Guvernul României, 2013). According to the IUCN classification, the "Iron Gates" Natural Park corresponds to category $\mathrm{V}$, being a protected area managed especially for landscape conservation and recreation (IUCN, 2014). Located in the south-western part of Romania (Pătroescu and Rozylowicz, 2000), the "Iron Gates" Natural Park is circumscribed by the Caraş-Severin and Mehedinţi counties (Cucu et al., 2012), overlapping for the most parts the Locvei, Almăj and Mehedinţi mountains, and the Mehedinţi Plateau (CCMESI, 2002). 
The area is characterized by a high biodiversity and geologic complexity, and by the presence of numerous cultural vestiges, all revealing the existence of a scientific and landscape heritage of international importance (Matacă, 2005).

The "Iron Gates" Natural Park is placed in the temperate continental climate area with Mediterranean influences (Bazac and Moldoveanu, 1996; Pătroescu et al., 2005). Annual temperatures are $11.5^{\circ} \mathrm{C}$ in Moldova Nouă and Șvinița, and $11.6^{\circ} \mathrm{C}$ in Drobeta Turnu Severin, while precipitations are between $559 \mathrm{~mm}$ in Orșova and 800-1,000 $\mathrm{mm}$ in Moldova Veche (Bazac and Moldoveanu, 1996; Matacă, 2005).

The diversity of soils present in the study area plays an important role in the structure and functions of both ecosystems and landscapes.

The vegetation is represented especially by forest ecosystems together with associations of shrubs, pastures, and ruderal elements. A specific element of the "Iron Gates" Natural Park is the presence of Sub Mediterranean vegetation (Călinescu and Iana, 1964; CCMESI, 2002; Pătroescu and Rozylowicz, 2000) which projects in the physiognomy of landscapes present in the area. Of special interest are the formations known as "şibleac" association of thermophile shrubs specific to the Danube Gorge (Călinescu and Iana, 1964; Pătroescu and Rozylowicz, 2000; Matacă, 2005).

The "Iron Gates" area is characterized by the presence of a high number of vascular plants (with 1,749 species and 120 different subspecies present in the park, they spread over 570 genus and 131 families, accounting for approximately $50 \%$ of the total species in Romania), of which Mediterranean and Sub Mediterranean species are represented by 217 taxon (Matacă, 2005).

Methods used in identifying landscape typologies in the "Iron Gates" Natural Park

We realized the identification of landscape typologies based on aerial images, existing maps and field researches. The first stage was represented by the identification of elements characterizing the composition of landscapes. The identification and classification of landscapes from the "Iron Gates" Natural Park is a complex process, with diverse criteria of functional, structural, spatial, temporal, and aesthetic nature used in delineating landscape types and subtypes (Ciocănea, 2013).

For the structural characteristics we used the morphological criteria expressed by the form, type and texture, but also included elements, either of natural or anthropic origin (Ciocănea, 2013; Drăguţ, 2000). We delineated the functional characteristics based on the functions identified in the field, while for the spatial-temporal characteristics of anthropic landscapes we considered the form, geographic position, and territorial expansion (Ciocănea, 2013; Jucu, 2010).

We constructed the landscape typologies based mainly on the land use and land cover, which we considered to directly project on categories of natural landscapes, especially agricultural and forest landscapes (Niculae, 2012). In delineating anthropic landscapes we used two main aspects: economic criteria (agricultural and industrial activities) and socialdemographic criteria (based on the number of inhabitants and the type of settlement - urban or rural) (Niculae, 2012; Perşu and Nancu, 2009; Vert, 2001). 


\section{Analysis of landscape dynamic in the "Iron Gates" Natural Park}

We evaluated landscape dynamic in the "Iron Gates" Natural Park based on the spatial database established by the European Environmental Agency (EEA) in the framework of the CORINE LandCover (CLC) project. We selected spatial data in a raster format and a 100*100 meters resolution for the years 1990 and 2006 (data available at the links http://www.eea.europa.eu/data-and-maps/data/corine-land-cover-1990-raster-3 and http://www.eea.europa.eu/data-and-maps/data/corine-land-cover-2006-raster-3). Using Arcgis 9.3 we projected the initial data in the Stereo 70 system keeping the $100 * 100$ resolution. Based on the data we obtained land use and land cover maps (Figs. 1 and 2) specific to the study area.

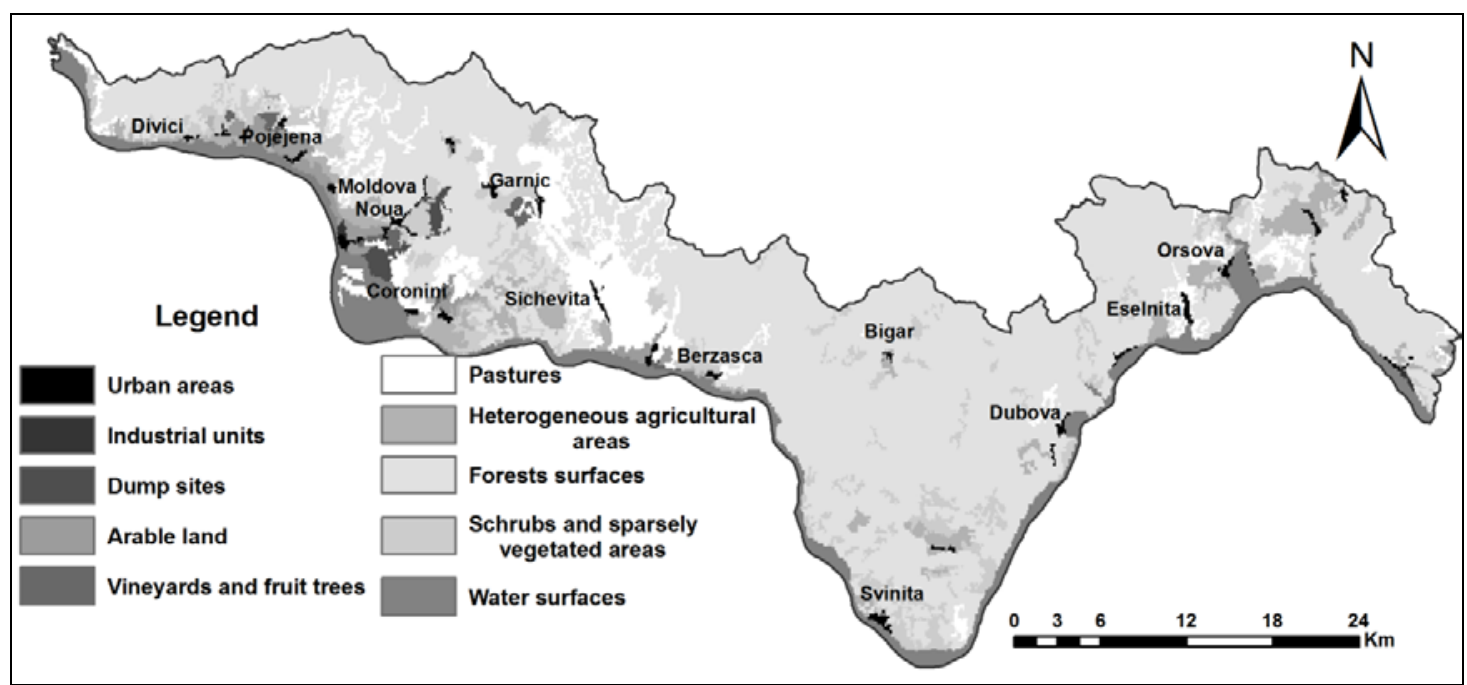

Figure 1: Land use and land cover classes in the "Iron Gates” Natural Park for the year 1990 (CLC 1990).

Based on the situations identified in the field and the objectives of our study, we reclassified the 19 classes resulting from CLC data level III (both for 1990 and 2006) into 10 classes (Tab. 1), each with a corresponding code from one to 10 . The resulting land use and land cover classes are corresponding to the main categories of landscapes identified in the "Iron Gates" Natural Park.

To evaluate the similitudes between the reference map and the compared one (Geri et al., 2010), we calculated the kappa coefficient of Cohen (KIA) (Cohen, 1960, 1968) for the main land uses and land cover in the "Iron Gates" Natural Park, as well as for the entire study area (Rosenfield and Fitzpatrick-Lins, 1986).

Based on the CLC databases, we identified and prioritized the main processes of transformation in the study area (Niculae, 2012; Feranec et al., 2000; Haines-Young and Weber, 2006; Perdigao and Christensen, 2000). 


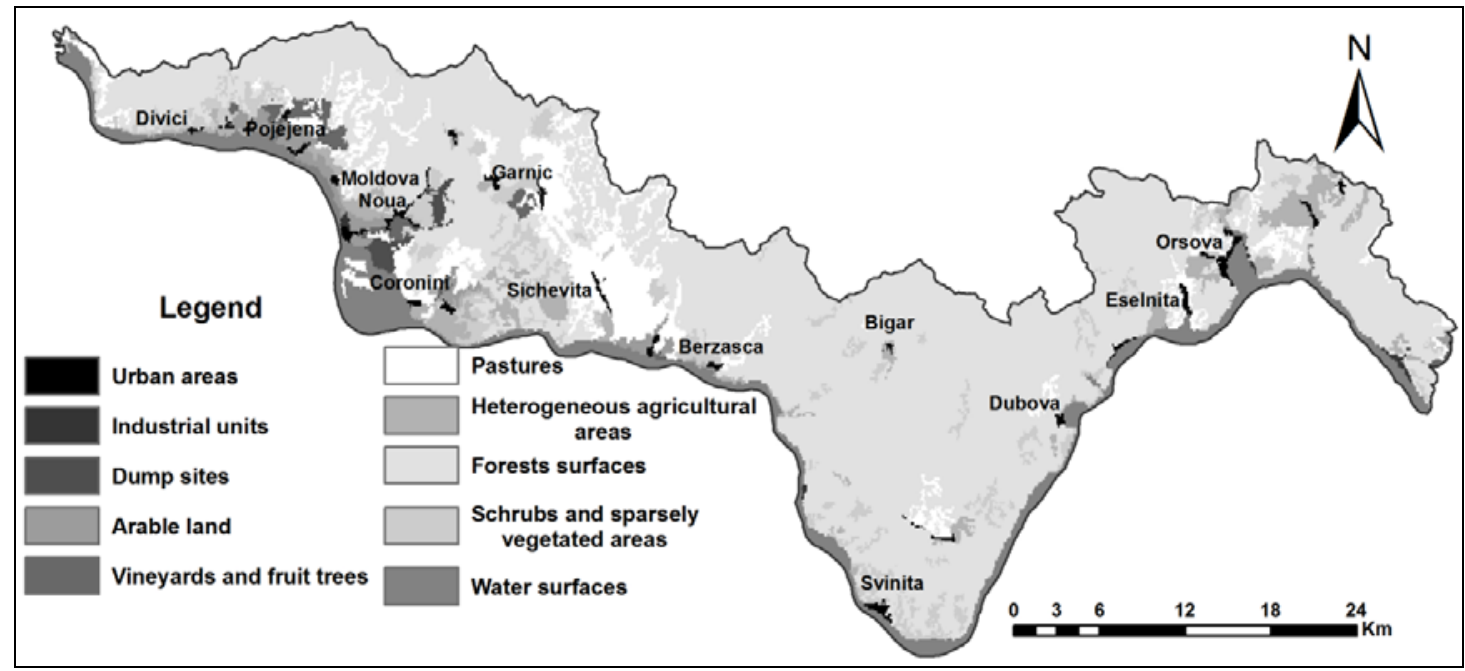

Figure 2: Land use and land cover classes in the "Iron Gates” Natural Park for the year 2006

(CLC 2006).

Table 1: Reclassified land use and land cover classes in the "Iron Gates” Natural Park (Bossard et al., 2000).

\begin{tabular}{|c|c|c|c|c|}
\hline $\begin{array}{c}\text { CLC } \\
\text { Level I } \\
\text { code }\end{array}$ & $\begin{array}{l}\text { CLC } \\
\text { Level II } \\
\text { code }\end{array}$ & $\begin{array}{c}\text { CLC } \\
\text { Level III } \\
\text { code }\end{array}$ & $\begin{array}{l}\text { Reclassified } \\
\text { code }\end{array}$ & $\begin{array}{c}\text { Name of } \\
\text { reclassified classes }\end{array}$ \\
\hline \multirow{3}{*}{1.} & 11 & 112 & 1 & Urban areas \\
\hline & 12 & $121 ; 123$ & 2 & Industrial units \\
\hline & 13 & $131 ; 132$ & 3 & Mineral extraction and dump sites \\
\hline \multirow{4}{*}{2.} & 21 & 211 & 4 & Arable land \\
\hline & 22 & $221 ; 222$ & 5 & Vineyards and fruit trees \\
\hline & 23 & 231 & 6 & Pastures \\
\hline & 24 & $242 ; 243$ & 7 & Heterogeneous agricultural areas \\
\hline \multirow{3}{*}{3.} & 31 & $311 ; 313$ & 8 & Forests \\
\hline & 32 & $321 ; 324$ & \multirow{2}{*}{9} & Shrubs and \\
\hline & 33 & $332 ; 333$ & & sparsely vegetated areas \\
\hline 5. & 51 & $511 ; 512$ & 10 & Water surfaces \\
\hline
\end{tabular}

In order to analyze land use dynamic that influence the dynamic of landscapes in the "Iron Gates" Natural Park, we delineated six transformation processes (Feranec et al., 2000; Feranec et al., 2010) which play important roles in landscape dynamic (Tab. 2).

Based on the transition matrix above, we quantified the surface for each process of transformation and their proportion (both to the total area of the "Iron Gates" Natural Park and to the total surface that has been modified). 
Table 2: Main transformation processes identified in the "Iron Gates" Natural Park (Feranec et al., 2010).

\begin{tabular}{|c|l|}
\hline $\begin{array}{c}\text { Process of transformation } \\
\text { industrial development) (PT1) }\end{array}$ & $\begin{array}{l}\text { Description } \\
\text { fransformation of agricultural lands (classes 21, 22, 23), } \\
\text { bodies (51) in surfaces dominated by built up areas }\end{array}$ \\
\hline $\begin{array}{c}\text { Intensification of agriculture } \\
\text { (PT2) }\end{array}$ & $\begin{array}{l}\text { Transformation of land uses of low intensity (semi natural } \\
\text { surfaces - classes 3.2, 3.3) in agricultural intensive fields, } \\
\text { and transformations between the agricultural classes of } \\
\text { level II and III }\end{array}$ \\
\hline $\begin{array}{c}\text { Reduction of agriculture } \\
\text { (PT3) }\end{array}$ & $\begin{array}{l}\text { Transformation of intensive used fields (classes 2.1, 2.2) in } \\
\text { land uses of low intensity }\end{array}$ \\
\hline $\begin{array}{c}\text { Forestation (PT4) } \\
\text { Deforestation (PT5) }\end{array}$ & $\begin{array}{l}\text { Natural forest regeneration and consequence of man-made } \\
\text { increasing the naturalness degree (converting classes 2.1, } \\
\text { 2.2, 2.3, 2.4, 3.3 into class 3.1) }\end{array}$ \\
\hline $\begin{array}{c}\text { Mands occupied by forests (class 3.1) converted in other } \\
\text { land use classes }\end{array}$ \\
\hline Management of water bodies \\
(wetlands) (PT6) & $\begin{array}{l}\text { Transformation of agricultural lands (classes 2.1, 2.2, 2.3 } \\
\text { and 2.4) in wetlands, including lands covered by waters } \\
\text { during floods }\end{array}$ \\
\hline Other changes (PT7) & $\begin{array}{l}\text { Other transformations: cultivation, extraction sites, } \\
\text { unclassified transformations, etc. }\end{array}$ \\
\hline
\end{tabular}

\section{RESULTS AND DISCUSSION}

Categories of landscapes identified in the "Iron Gates" Natural Park

In the "Iron Gates" Natural Park we identified two main landscape types (Fig. 3).

\section{A. Natural landscapes determined by physical and geographical characteristics}

Based on the differences regarding qualitative and quantitative aspects of elements included in the natural landscapes, we were able to differentiate two subcategories (CCMESI, 2014; Niculae, 2012): a) natural landscapes induced by the structural and petrographic relief, and b) landscapes imposed by the physiognomy and distribution of vegetation.

Landscapes determined by the structural and petrographic relief represent real elements of the natural heritage and include the following subcategories: mountain peak landscapes, tectonic and sedimentary basin landscapes, meadow landscapes, terraces landscapes, and the Danube Gorge landscape (Fig. 4A).

Landscapes dominated by vegetation elements include forest landscapes distributed in the mountainous units, the forested grasslands (on small surfaces and with increase fragmentation), and the specific landscape of the "Iron Gates" Natural Park of the vegetation formation known as "șibleac" (Fig. 4B) - secondary association resulted from the deforestation of the highest layers from the thermophile forests and containing now only elements of the lower layers such as downy oak, manna, wig, lilac, etc. (Matacă, 2005; Călinescu and Iana, 1964). 


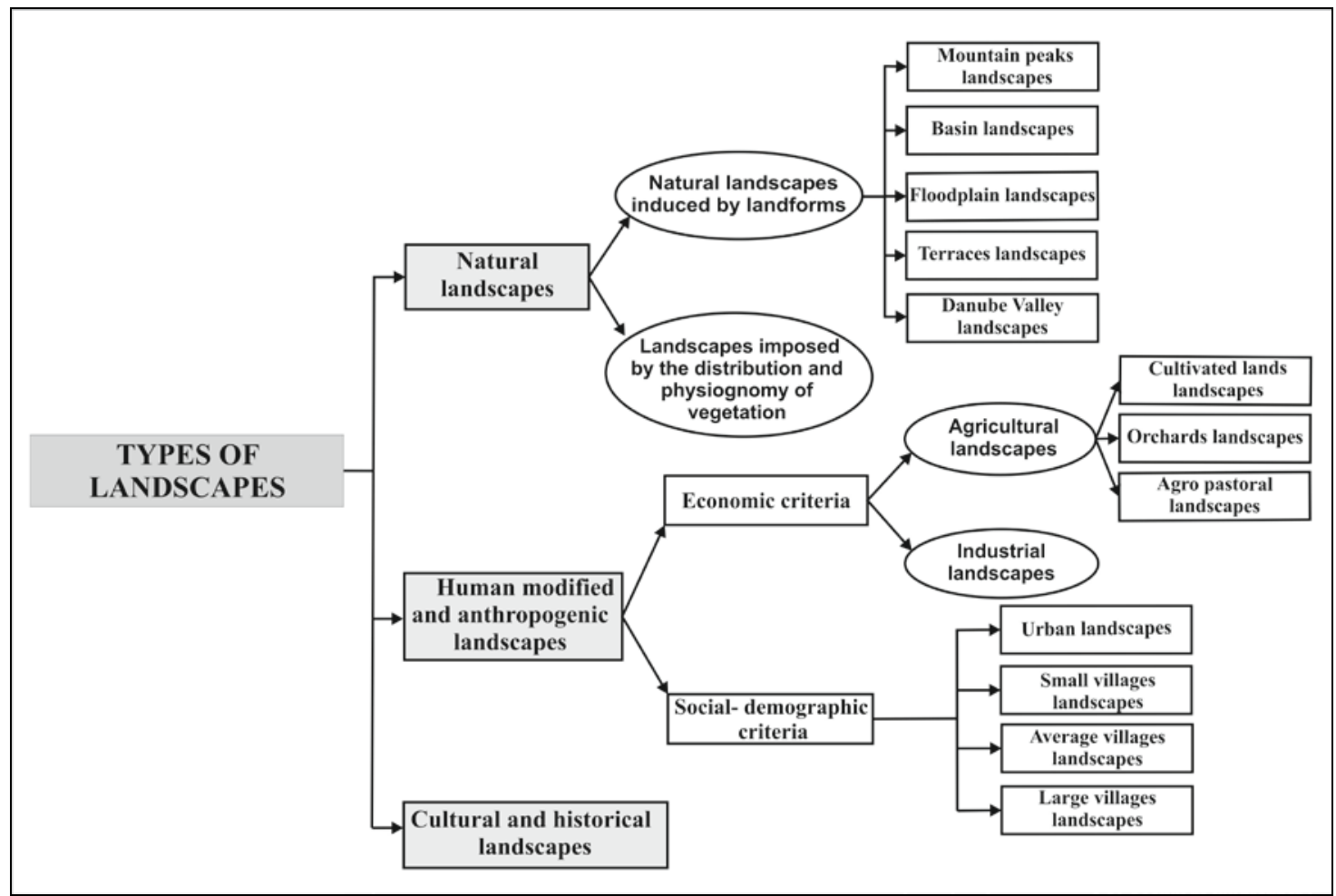

Figure 3: Landscape typologies in the "Iron Gates” Natural Park.
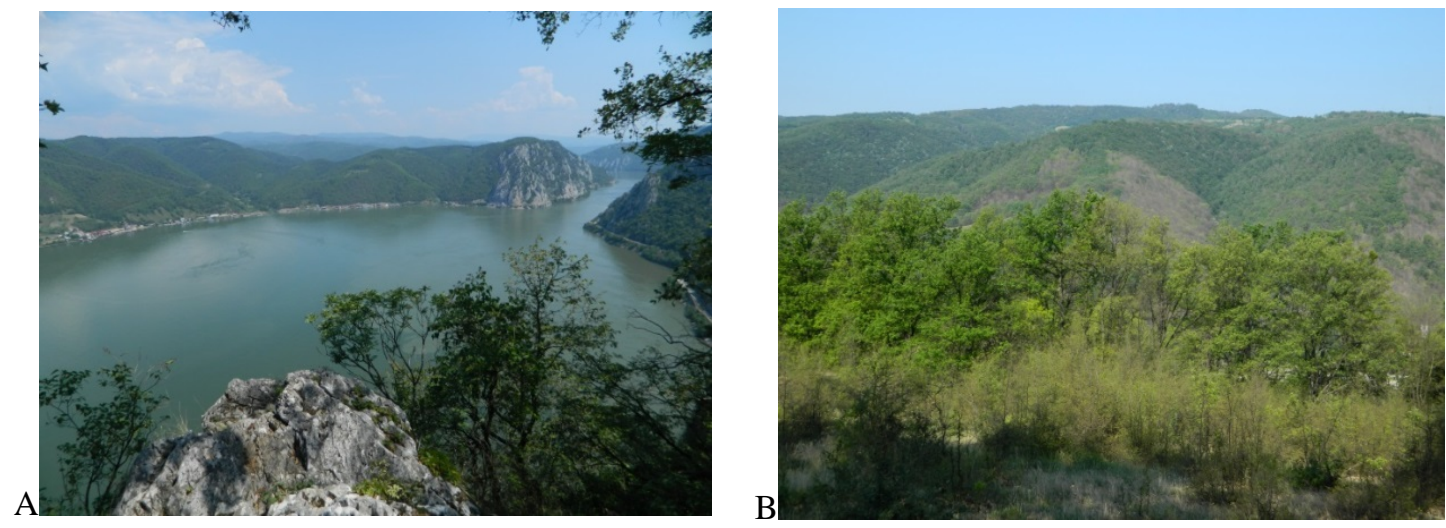

Figure 4: Landscape of the Danube Gorge and the Dubova Bay (A);

"şibleac" association on the Ciucaru Mare Peak (B).

\section{B. Anthropic landscapes}

Using the economic and social-demographic criteria, we identified in the "Iron Gates" Natural Park the following subtypes of anthropic landscapes (CCMESI, 2014): a) agricultural landscapes, b) industrial landscapes, and c) landscape of rural and urban settlements.

Agricultural landscapes determined by the main land uses are represented by subtypes as the landscape of closed cultivated lands (Figs. 5A and 5B), orchard landscapes, agropastoral landscapes specific to mountainous and basin areas, and mixed agricultural landscapes. 
Considering the social-demographic criteria, we identified the following subtypes: urban landscapes (Orșova, Moldova Nouă), landscape of small villages (Cârșie, Zăsloane, Eibenthal, etc.), landscape of medium villages (Gornea, Pojejena, etc.) and the landscape of large villages (Eșelnița, Berzasca, Coronini, etc.).
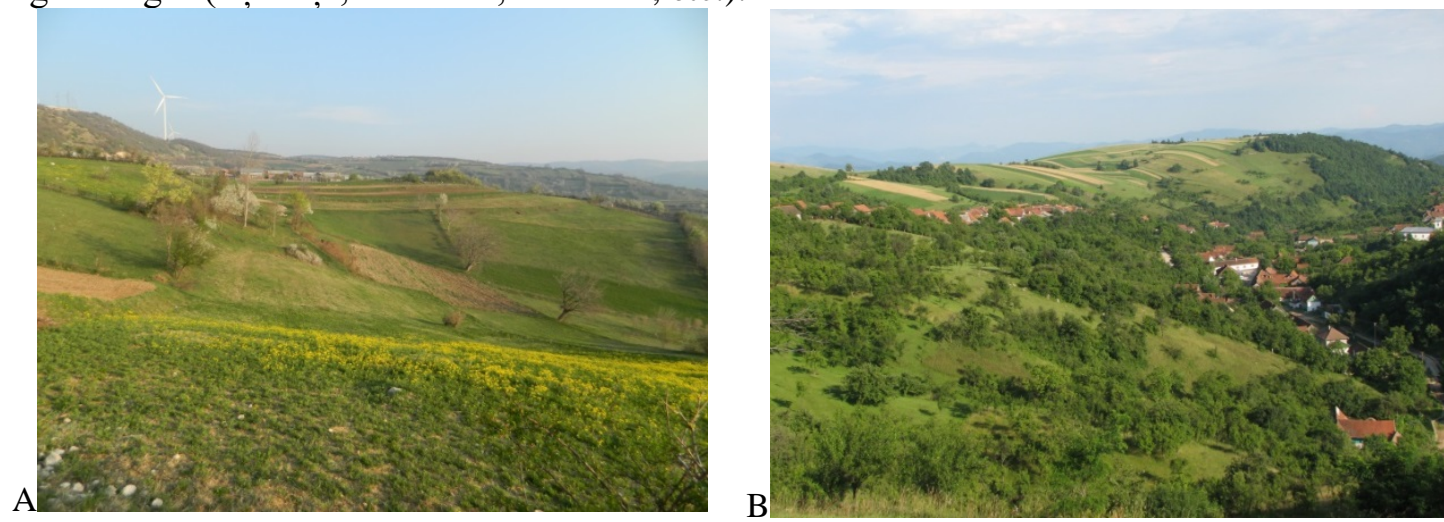

Figure 5: Agricultural landscapes identified on the Sfânta Elena (A) and Gârnic (B) plateaus.

A special category is represented by the cultural and historical landscapes determined by the elements of material and immaterial heritage (Schreiber et al., 2008). The constructed heritage is represented by buildings considered historical monuments or with architectural value, archaeological sites (Gornea, Schela Cladovei - where evidences of the oldest permanent settlement in Europe have been identified) (CCMESI, 2004), ruins of citadels and fortresses (Drencova, Divici, Trikule, Ladislau, etc.), traditional households, monasteries and churches (Vodița Monastery, Sfânta Ana Monastery, Baziaș Monastery, Eșelnița Church, Eibenthal Church, Berzasca Church, etc.). All these elements are harmoniously integrated with the elements of the small heritage: defence systems, crosses and trinities, water mills on the Cameniţa Valley, statues, etc.

\section{Landscape dynamic in the "Iron Gates" Natural Park}

Following the cross-tabulation analysis using ArcGis 9.3, we obtained a transition matrix (Tab. 3) which presents the value for each process of transformation, therefore representing a strong measurement of the spatial and temporal dynamic of landscapes in the “Iron Gates” Natural Park.

The quantification of changes in land use and land cover classes allowed us to record areas where the surfaces increased or reduced for each of the 10 landscape categories, and to establish the modification rates of their total surface (Tab. 4).

A number of six classes recorded surface increases in the 1990-2006 periods, while the total surface in the case of three classes reduced. Only the surface of mineral extraction and dump sites remained constant for the analyzed period.

Orchards and vineyards recorded the most significant increases (+687 ha, 93\%), followed by the lands occupied by industrial activities (+86 ha, $69 \%$ ), built up surfaces (+87 ha, $6 \%$ ), and forest surfaces (+1884 ha, $2.3 \%$ ).

Significant decreases were recorded by the class of shrubs, rare vegetation and natural grasslands (-2254 ha, 22\%), and the class of mixt agricultural lands ( $-760 \mathrm{ha}, \sim 11.5 \%$ ).

The surface that suffered no modifications in the analyzed period is of 122,502 ha, representing $\sim 95.6 \%$, while the modified surfaces represent 5,696 ha ( 4.4\%). 
Table 3: Transition matrix resulted from the comparison of the two datasets; * Land use and land cover classes according to table 1.

\begin{tabular}{|c|c|c|c|c|c|c|c|c|c|c|c|}
\hline Classes & 2006 & & & & & & & & & & \\
\hline 1990 & $1^{*}$ & 2 & 3 & 4 & 5 & 6 & 7 & 8 & 9 & 10 & Total \\
\hline $1^{*}$ & 1,282 & 47 & 0 & 0 & 0 & 2 & 35 & 8 & 0 & 0 & 1,374 \\
\hline 2 & 0 & 125 & 0 & 0 & 0 & 0 & 0 & 0 & 0 & 0 & 125 \\
\hline 3 & 0 & 0 & 698 & 0 & 0 & 0 & 0 & 0 & 0 & 0 & 698 \\
\hline 4 & 0 & 0 & 0 & 2,074 & 34 & 0 & 1 & 0 & 0 & 4 & 2,113 \\
\hline 5 & 0 & 0 & 0 & 0 & 738 & 0 & 0 & 0 & 0 & 0 & 738 \\
\hline 6 & 0 & 0 & 0 & 0 & 0 & 12,653 & 0 & 92 & 119 & 0 & 12,864 \\
\hline 7 & 148 & 15 & 0 & 8 & 16 & 204 & 5,408 & 259 & 486 & 101 & 6,645 \\
\hline 8 & 15 & 0 & 0 & 0 & 0 & 60 & 235 & 82,128 & 424 & 6 & 82,868 \\
\hline 9 & 0 & 24 & 0 & 0 & 637 & 257 & 151 & 2220 & 6,784 & 0 & 10,073 \\
\hline 10 & 16 & 0 & 0 & 6 & 0 & 0 & 55 & 5 & 6 & 10,612 & 10,700 \\
\hline Total & 1,461 & 211 & 698 & 2,088 & 1,425 & 13,176 & 5,885 & 84,712 & 7,819 & 10,723 & 128,198 \\
\hline
\end{tabular}

Table 4: Changes recorded in land use and land covers classes between 1990-2006; * Values represent differences between increases and reductions for the surface of each class.

\begin{tabular}{|c|c|c|c|c|c|}
\hline $\begin{array}{c}\text { Land use and } \\
\text { land cover } \\
\text { classes }\end{array}$ & $\begin{array}{c}\text { Area } \\
1990 \text { (ha) }\end{array}$ & $\begin{array}{c}\text { Area } \\
2006(\text { ha) }\end{array}$ & $\begin{array}{c}\text { Areas with } \\
\text { increases (ha) } \\
(1990-006)\end{array}$ & $\begin{array}{c}\text { Areas with } \\
\text { reduction (ha) } \\
(1990-2006)\end{array}$ & $\begin{array}{c}\text { Difference } \\
\text { (ha) (1990- } \\
2006)^{*}\end{array}$ \\
\hline 1 & 1,374 & 1,461 & 179 & 92 & +87 \\
\hline 2 & 125 & 211 & 86 & 0 & +86 \\
\hline 3 & 698 & 698 & 0 & 0 & 0 \\
\hline 4 & 2,113 & 2,088 & 14 & 39 & -25 \\
\hline 5 & 738 & 1,425 & 687 & 0 & +687 \\
\hline 6 & 12,864 & 13,176 & 523 & 211 & +312 \\
\hline 7 & 6,645 & 5,885 & 477 & 1,237 & -760 \\
\hline 8 & 82,868 & 84,712 & 2,584 & 740 & $+1,844$ \\
\hline 9 & 10,073 & 7,819 & 1,035 & 3,289 & $-2,254$ \\
\hline 10 & 10,700 & 10,723 & 111 & 88 & +23 \\
\hline
\end{tabular}

These results are confirmed by the value of the Kappa concordance index calculated for the two time periods regarding the land use and land cover. The value of 0.93 indicates a reduced spatial modification of surfaces (Cohen, 1960; Cohen, 1968) and a high concordance $(0.80<$ KIA < 1.00) (Altman, 1991).

The existing relationships between the six processes of transformation (PT1-PT6) and the classes derived from the CLC level II database allowed us to establish the matrix of transformations (Tab. 5) recorded for each land use and land cover class in 1990-2006.

Based on the correlation between the values from the transition matrix (resulted from the comparison of the two data sets) and the matrix of transformation processes among the land use and land cover classes, we calculated the percent of surfaces affected by the main processes of transformation (PT1-PT6) in relation to the total surface of the "Iron Gates" Natural Park and the total modified surface (Feranec et al., 2010) (Tab. 4). 
Table 5: Matrix of transformation processes among the land uses and land cover classes. * The numbers 1 to 10 in the first column and row correspond to the reclassified codes from table 1 , and those in brackets to the CLC level II codes; ** 1 - urbanisation; 2 - intensification of agriculture; 3 - reduction of agriculture; 4 - forestation; 5 deforestation; 6 - management of water bodies (wetlands); 7 - other changes.

\begin{tabular}{|c|c|c|c|c|c|c|c|c|c|c|}
\hline Classes & \multicolumn{10}{|c|}{1990} \\
\hline 2006 & $\begin{array}{c}1^{*} \\
(11)\end{array}$ & $\begin{array}{c}2 \\
(12)\end{array}$ & $\begin{array}{c}3 \\
(13)\end{array}$ & $\begin{array}{c}4 \\
(21)\end{array}$ & $\begin{array}{c}5 \\
(22)\end{array}$ & $\begin{array}{c}6 \\
(23)\end{array}$ & $\begin{array}{c}7 \\
(24)\end{array}$ & $\begin{array}{c}8 \\
(31)\end{array}$ & $\begin{array}{c}9 \\
(32 ; 33)\end{array}$ & $\begin{array}{c}10 \\
(51)\end{array}$ \\
\hline $1(11)$ & 0 & 7 & 7 & $1^{* *}$ & 1 & 1 & 1 & 1 & 1 & 1 \\
\hline $2(12)$ & 7 & 0 & 7 & 1 & 1 & 1 & 1 & 1 & 1 & 1 \\
\hline $3(13)$ & 7 & 7 & 0 & 1 & 1 & 1 & 1 & 1 & 1 & 1 \\
\hline $4(21)$ & 7 & 7 & 7 & 0 & 3 & 2 & 2 & 5 & 2 & 7 \\
\hline $5(22)$ & 7 & 7 & 7 & 2 & 0 & 2 & 2 & 5 & 2 & 7 \\
\hline $6(23)$ & 7 & 7 & 7 & 3 & 3 & 0 & 3 & 5 & 2 & 7 \\
\hline $7(24)$ & 7 & 7 & 7 & 3 & 3 & 2 & 0 & 5 & 2 & 7 \\
\hline $8(31)$ & 7 & 7 & 7 & 4 & 4 & 4 & 4 & 0 & 4 & 4 \\
\hline $9(32,33)$ & 7 & 7 & 7 & 7 & 7 & 7 & 7 & 5 & 0 & 7 \\
\hline $10(51)$ & 7 & 7 & 6 & 6 & 6 & 6 & 6 & 6 & 6 & 0 \\
\hline
\end{tabular}

Table 6: The main processes of transformation identified in the "Iron Gates" Natural Park; * Percent calculated from the total modified surface; ** Percent calculated from the total surface of the "Iron Gates" Natural Park.

\begin{tabular}{|c|c|c|c|}
\hline $\begin{array}{c}\text { Processes of transformation } \\
\text { Urbanisation (including industrial } \\
\text { development) (PT1) }\end{array}$ & Surface (ha) & Percent (\%)* & Percent (\%)** \\
\hline $\begin{array}{c}\text { Intensification of agriculture } \\
\text { (PT2) }\end{array}$ & 1,103 & 3.83 & 0.17 \\
\hline Reduction of agriculture (PT3) & 205 & 19.36 & 0.86 \\
\hline Forestation (PT4) & 2,576 & 3.60 & 0.16 \\
\hline Deforestation (PT5) & 719 & 12.22 & 2.01 \\
\hline $\begin{array}{c}\text { Management of water bodies } \\
\text { (wetlands) (PT6) }\end{array}$ & 111 & 1.95 & 0.56 \\
\hline Other changes (PT7) & 764 & 13.41 & 0.09 \\
\hline Unmodified surface & 122,502 & - & 0.6 \\
\hline Total modified surface & 5,696 & 100 & 4.44 \\
\hline
\end{tabular}

Changes in land use and land cover represent an important indicator in evaluating the dynamic of landscapes (Feranec et al., 2002) we identified in the "Iron Gates" Natural Park. The main categories of landscapes represent elements of the natural and cultural heritage that increase the value of this protected area of national, regional and worldwide interest. Natural landscapes determined by the physical and geographical characteristics, together with the anthropic landscapes generated by social and economic factors, represent an important element that was considered in the establishment of the protected area regime. 
The characteristics of the relief and land cover generate a high proportion of surfaces covered by forests; therefore, forest landscapes are dominant in the "Iron Gates" Natural Park, being accompanied by the agricultural and agro-pastoral landscapes.

Landscapes of urban and rural settlements are present along the Danube and on its tributary valleys, but also on the mountainous plateaus where the morphometric characteristics of the relief represented a favourability factor in the historical evolution of settlements.

Elements of the material and immaterial heritage (Schreiber et al., 2008) supplement the typologies of identified landscapes increasing the personality of local communities from the "Iron Gates" Natural Park.

The dynamic of landscapes determined by the land use and land cover did not record significant changes in the analyzed interval (with modification on only $\sim 4.4 \%$ of the total surfaces), sustained also by the value of the KIA index (0.93) representing reduced spatial modification of landscapes in 2006 compared to 1990.

The highest surface increases were recorded for forest landscapes, orchards, and agropastoral landscapes with pastures. Having a protected area status, the "Iron Gates" region benefits from a high degree of protection and conservation, measures that directly target forest landscapes. In the "Iron Gates" Natural Park forest surfaces have increased either through natural regeneration, or anthropic plantations for increasing the naturalness or fixating degraded lands.

Surfaces occupied by shrubs and rare vegetation, corroborated with mixed agricultural uses (heterogeneous), recorded significant decreases in surfaces, in the favour of forest surfaces for the expansion of pastures, or by the development of residential and industrial areas required for satisfying the human needs (Niculae and Pătroescu, 2011). Previous studies (Cucu et al., 2013) have revealed that the most aggressive threats to the protected areas at "Iron Gates" Natural Park are represented by industrial activities, different pollution, and human impact.

Values extracted from the Corine Land Cover model are different than those obtained from statistical data existing at county and national level. These differences are generated mainly due to data interpretation and the methodology of classification for different land uses and land covers established the European Environmental Agency (Feranec et al., 2000).

According to the management plan of the "Iron Gates" Natural Park - approved by the Romanian Government in December 2013 (Guvernul Romaniei, 2013) - residential, industrial, and resource exploitation spaces have expanded especially in the sustainable development zone as established by the present legislation.

Our research on the processes of transformation in the "Iron Gates" Natural Park showed that forestations (either by human actions or natural causes) have the highest proportion ( $\sim 2 \%$ of the total area and $\sim 45 \%$ of the surface modified between 1990 and 2006). In addition, the increase of agricultural activities was present on $\sim 0.9 \%$ of the park area $(\sim$ $20 \%$ of the surface modified between 1990 and 2006). These values have been generated particularly by the dominance of rural communities in the park and by the relief conditions favouring these types of economic activities.

\section{CONCLUSIONS}

In the framework of present environmental, social, and economic changes, landscapes are generally confronted to an accelerated dynamic. This is not the case in the "Iron Gates" Natural Park, where the protected area regime and the characteristics of social and economic elements determined changes in fewer than $5 \%$ of the total surface of landscapes. 
The typologies of landscapes identified in the "Iron Gates" Natural Park can serve as support for both future studies and public administration. Our analysis represent a model for the dynamic of landscapes which can be improved by adding data of a better special resolution or integrating the view of residents as an important element in landscape evaluation.

\section{ACKNOWLEDGMENTS}

We would like to acknowledge the support of our colleagues from the Centre for Environmental Research and Impact Studies (CCMESI) - University of Bucharest. In addition, we want to appreciate the contribution of the "Iron Gates" Natural Park Administration in all of our field researches and data gathering campaigns.

\section{REFERENCES}

1. Altman D. G., 1991 - Practical statistics for medical research, Chapman and Hall, London, 624.

2. Bazac G. and Moldoveanu M., 1996 - Unele caracteristici ale influențelor mediteraneene asupra climei din Sud-Vestul României, Terra, XXVIII, 86-97. (in Romanian)

3. Călinescu R. and Iana S., 1964 - Considerațiuni biogeografice asupra Defileului Dunării, Analele Universităţii București, Seria Geologie-Geografie, XIII, 1, 151-167. (in Romanian)

4. CCMESI, 2002 - Metodologie de inventariere a habitatelor populate de țestoasa lui Hermann în arealul Parcului Natural Porțile de Fier, in Pătroescu M., (ed.), LIFE00NAT/RO/7171, Rapoarte de acțiune, Universitatea din București, CCMESI. (in Romanian)

5. CCMESI, 2004 - "Iron Gates” Natural Park, LIFE Nature project LIFE/NAT/RO/7171, University of Bucharest, CCMESI.

6. CCMESI, 2014 - Studiu privind întocmirea metodologiei de identificare, caracterizare şi clasificare a peisajelor în zona transfrontalieră Parcul Natural Porţile de Fier şi Parcul Naţional Djerdap, Raport final realizat în cadrul proiectului Integrated Management Of Biological And Landscape Diversity For Sustainable Regional Development And Ecological Connectivity In The Carpathians (Bioregio Carpathians), 75. (in Romanian)

7. Ciocănea C. M., 2013 - Modificări structurale şi funcţionale ale peisajelor urbane determinate de modelele de consum ale societăţii, Studiu de caz - Sectorul 3 al Municipiului Bucureşti, Teză de doctorat, Facultatea de Geografie, Universitatea din Bucureşti, 239. (in Romanian)

8. Cohen J., 1960 - A coefficient of agreement for nominal scales, Educational and Psychological Measurement, 20, 1, 37-46.

9. Cohen J., 1968 - Weighted kappa: Nominal scale agreement provision for scaled disagreement or partial credit, Psychological Bulletin, 70, 213-220.

10. Coppin P., Jonckheere J., Nackaerts K., Muys B. and Lambin E., 2004 - Digital change detection methods in ecosystem monitoring: a review, International Journal of Remote Sensing, 25, 9, 1565-1596.

11. Council of Europe, 2000 - European Landscape Convention. Available at: http://conventions.coe.int/Treaty/Commun/QueVoulezVous.asp?NT=176\&CM=8\&CL=ENG, accessed on 6.11.1982.

12. Cucu L. A., Niculae M. I. and Pătroescu M., 2012 - Hierarchical analysis of the threats for species of Community Interest in the "Iron Gates" Natural Park, Romania, Forum Geografic, Studii și cercetări de geografie și protecţia mediului, 12, 1, 52-58.

13. Cucu L. A., Niculae M. I. and Pătroescu M., 2013 - Species management in the "Iron Gates" Natural Park: an overview of zonation effectiveness, Present Environment \& Sustainable Development, 7, 2, 145-155.

14. Drăguţ L., 2000 - Geografia peisajului, Edit. Presa Universitară Clujeană, Cluj, 119. (in Romanian) 
15. Faburel G. (coord.), Altaber C., Chevallier K., Meyer L. and Gageonnet C., 2012 - Le bien-être et ses paysages comme territoires des infrastructures de transport terrestre, Conflits d'acteurs, enjeux de valeurs et savoirs paysagers, du Bureau de recherches Aménités pour le Ministère de l'Ecologie, du Développement Durable et de l'Energie, Programme scientifique Infrastructures de Transport Terrestre Ecologie Paysages (ITTECOP), 1-19.

16. Feranec J., Suri M., Otahel J., Cebecauer T., Kolar J., Soukup T., Zdenkova D., Waszmuth J., Vajdea V., Vajdea A. M. and Niţică C., 2000 - Inventory of major landscape changes in the Czech Republic, Hungary, Romania and Slovak Republic 1970s-1990s, International Journal of Applied Earth Observation and Geoinformation, 2, 2, 129-139. (in French)

17. Feranec J., Śúri M., Cebecauer T. and Ot’ahel' J., 2002 - Methodological aspects of landscape changes detection and analysis in Slovakia applying the CORINE land cover databases, Geografický časopis, 53, 3, 271-288.

18. Feranec J., Jaffrain G., Soukup T. and Hazeu G., 2010 - Determining changes and flows in European landscapes 1990-2000 using CORINE land cover data, Applied Geography, 30, 19-35.

19. Geri F., Amici V. and Rocchini D., 2010 - Human activity impact on the heterogeneity of a Mediterranean landscape, Applied Geography, 30, 370-379.

20. Grigorovschi M., Dida M., Gafar M., Erca C., Retegan E. and Suler T., 2007 - Ghid de valorificare a patrimoniului rural, Casa de Presă şi Edit. Tribuna, Sibiu, 172. (in Romanian)

21. Gruia L. and Glăvan V., 1979 - Posibilități de îmbunătățire a potențialului agro și silvocultural al unor soluri din Defileul Dunării, Analele Universității din București, XXVIII, 2, 89-93. (in Romanian)

22. Guvernul României, 2013 - Hotărârea nr. 1048/2013 pentru aprobarea Planului de management și a Regulamentului Parcului Natural Porțile de Fier, Monitorul Oficial al României, nr. 119/2014, I. (in Romanian)

23. Haines-Young R. and Weber J. L., 2006 - Land accounts for Europe 1990-2000, Towards integrated land and ecosystem accounting, EEA Report, 11, European Environment Agency, Copenhagen, 108.

24. IUCN, 2014 - IUCN Protected Areas Categories System, available at http://www.iucn.org/about/work/programmes/gpap_home/gpap_quality/gpap_pacategories/ accessed on 7.02.2014.

25. Jucu I. S., 2010 - Cadrul teoretic şi metodologic de analiză al procesului de restructurare urbană specific oraşului românesc post-socialist, Analele Asociaţiei Profesionale a Geografilor din România, 1, 1, 67-84. (in Romanian)

26. Matacă S. S., 2005 - Parcul Natural Porțile de Fier, Floră, vegetație și protecția naturii, Edit. Universitaria, Craiova, 550. (in Romanian)

27. Niculae M. I., 2012 - Evoluția spațială și temporală a peisajelor rurale din Subcarpații cuprinși între Buzău și Râmnicu Sărat, Edit. Universității din București, București, 282. (in Romanian)

28. Niculae M. I. and Pătroescu M., 2011 - Quantifying forest ecosystems fragmentation in the Subcarpathians between the Râmnicu Sărat and the Buzău valleys, Romania, using landscape metrics, Forum Geografic, Studii şi cercetări de geografie şi protecţia mediului, 10, 1, 187-194.

29. Pătroescu M. and Rozylowicz L., 2000 - Natural Transborder Parks: the direction of Biodiversity preservation in Romania, in Crabbe et al. (eds), Implementing ecological integrity, Kluwer Academic Press, 101-113.

30. Pătroescu M., Toma S., Sasaki L. and Apostol G., 2000 - Priorities in the re-habilitation and renaturation of rural landscape of the Romanian Plaine, Southern Romania, Analele Universităţii Bucureşti, Seria Geografie, 95-102.

31. Pătroescu M., Iojă C., Rozylowicz L., Popescu V., Tetelea C., Dumitrașcu D. and Necșuliu R., 2005 - Planul de management al Parcului Natural Porţile de Fier - Partea I, caracterizare complexă a arealului studiat, in Pătroescu M. (ed.), Raport de cercetare, proiectul LIFE00/NAT/RO/7171. (in Romanian) 
32. Pătru-Stupariu I., 2011 - Peisaj şi gestiunea durabilă a peisajului, Aplicaţii la Culoarul transcarpatic Bran-Rucăr-Dragoslavele, Edit. Universităţii din Bucureşti, Bucureşti, 214. (in Romanian)

33. Perdigao V. and Christensen S., 2000 - The Lacoast Atlas: Land cover changes in European coastal zone, S.P.I.00.39 EN, European Commission, DJ-Joint Research Centre, Ispra.

34. Perșu M. and Nancu D., 2009 - Types of rural landscapes in the Oltenian Subcarpathian depressions, Forum geographic, Studii şi cercetări de geografie şi protecţia mediului, 8, 124130.

35. Prieur M., 2006 - Paysage et approches sociale, économique, culturelle et écologique, in Conseil de l'Europe (2006) Paysage et développement durable, Les enjeux de la Convention européenne du paysage, 9-29. (in French)

36. Rosenfield G. H. and Fitzpatrick-Lins K., 1986 - A coefficient of agreement as a measure of thematic classification accuracy, Photogrammetric Engineering and Remote Sensing, 52, 2, 223227.

37. Rozylowicz L., 2008 - Metode de analiză a distribuției areal - geografice a țestoasei lui Hermann (Testudo hermanni Gmelin, 1789) în România, Studiu de caz Parcul Natural Porțile de Fier, Edit. Universităţii din București, București, 169. (in Romanian)

38. Schreiber W., Cocean P., Ciangă N. and Benedek J., 2008 - Protection and valorization of cultural landscapes in Transylvania, in Infrastructure and Ecology of Rural Area 12, Monograph, Cultural landscape, Protecting histroical cultural landscape to strengthen regional identities and local economies, Polish Academy of Science, Crakow Branch Commission of Technical Infrastructure, Crakow, Polish, 155-161.

39. Thiha Weeb E. L. and Honda K., 2007 - Biophysical and policy drivers of landscape change in a central Vietnamese district, Environmental Conservation, 34, 164-172.

40. Toma S., 2008 - Dinamica structurilor agrare și proiecția lor în ecologia peisajelor rurale din Câmpia Română, Teză de doctorat, Universitatea din București, București, 362. (in Romanian)

41. Vert C., 2001 -Tipuri de peisaje rurale în Banat, MIRTON, Timișoara, 331. (in Romanian) 